\title{
THE VALUE OF OESTRIN FOR PREMATURE BABIES
}

BY

\author{
ALAN MONCRIEFF, M.D., F.R.C.P. \\ Physician to the Children's Department, Middlesex Hospital; Assistant \\ Paediatrician, Queen Charlotte's Maternity Hospital.
}

Following the suggestion made by Aschheim $^{1}$ in 1927 that premature babies might be beneficially influenced by the administration of oestrin there have been numerous papers on the subject, especially in the German literature. The results have been conflicting and when good effects have been claimed it is not always clear that adequate attempts have been made to secure proper controls for comparison. In 1933 Dr. A. N. Macbeth of the Organon Laboratories suggested that the work should be repeated in this country and a supply of 'Menformon' was kindly offered for this purpose. This was administered to certain premature babies as described below. At the same time, while in receipt of a personal part-time grant from the Medical Research Council, the author undertook a more extensive trial of two preparations of oestrin supplied on behalf of the Medical Research Council by British Drug Houses, Ltd. In respect of this trial guidance was afforded by Dr. A. S. Parkes concerning dosage, the type of preparation and the solvent used.

The arguments in favour of administering oestrin to premature infants are based upon the fact, mentioned by Martin $^{2}$, that the blood of new-born babies contains a comparatively large amount of oestrin. This is rapidly excreted by the kidneys and ceases to be present in the urine after about four days. It is argued that the baby born before term is at a disadvantage because it lacks the stimulus of the oestrin which would have continued to abound in its blood until the full term of pregnancy had the foetus remained in utero. The absence of this stimulus is held to be responsible, at any rate in part, for the drowsiness and general depressed condition of metabolism which constitutes the major handicap of the premature baby in the early days of life. The administration of oestrin, according to its advocates, remedies this deficiency and thereby enables the premature infant to gain weight and 
improve its state generally in a more satisfactory way than the untreated infant.

\section{Previous work.}

This claim can now be examined by means of a brief critical review of the literature.

Martin $^{2}$ appears to have been the first to publish, in 1929, any account of clinical trials and he claims to have been working at the subject independently of the suggestion made by Aschheim, referred to above. He used an oily suspension of oestrin, sweetened by saccharine and gave it by the mouth to infants weighing less than $2 \mathrm{kgm}$. in doses of 100 mouse units (M.U.) per kgm. He first treated eight babies beginning on the fourth day (the day when the urine normally became free from oestrin) and claimed a steady rise in weight after a preliminary fall for one to two days, all of the babies developing in a manner more like full-time infants than prematures. A further series of eight premature infants were treated from the first day of life and they showed no loss of weight. No contemporary controls were used in assessing the results. Reiche" in the following year reported the use of ' unden' - an oily solution of oestrinfor thirty-two premature infants and he compared the results with those obtained in his clinic for the preceding ten years, mainly basing his conclusions upon mortality rates. He claimed that for infants under $1200 \mathrm{gm}$. the mortality was reduced from 84.5 per cent. to 20 per cent.; for those weighing between 1200 and $1500 \mathrm{gm}$. the reduction was from 59 to 14.3 per cent.; for those between 1500 and $2000 \mathrm{gm}$. the reduction was from 47 to 33 per cent.; and for infants over $2000 \mathrm{gm}$. there was no appreciable change. All the deaths in the series occurred in the first week. The same dosage (100 M.U. per kgm.) was used as by Martin. Schiller $^{4}$ used a purer preparation, namely folliculin, and he gave it by injection generally in a dosage of 20 to $40 \mathrm{M}$.U. daily, although in some cases improvement was claimed from a daily dose of only 4 M.U. In all, sixty-eight premature infants were treated and it is claimed that a notable effect was obtained in the shape of steeply rising weight curve, usually after only a small preliminary loss, often regained on the second day. If the injections of oestrin were stopped or decreased the rise in weight was noted to be arrested. Mügel ${ }^{j}$ used ' unden' given by the mouth (100 M.U. per kgm.) for thirty-nine premature infants. The results obtained were compared with the progress made by untreated infants, all being under the control of the same nursing-sister. In all weight groups better progress was made by the treated babies. The records, however, with two exceptions, refer to babies over $2000 \mathrm{kgm}$. (approximately $4 \mathrm{lb}$.) and deal with progress for only ten days. Nölle ${ }^{6}$, in reviewing the subject of female sex hormones, mentions the use of 'progynon' for two premature babies in a daily dose corresponding to approximately 125 M.U. with good results. Kulka ${ }^{7}$ used ' unden' by the mouth in doses of 100 M.U. per kgm. daily for thirty-seven premature infants and his impression was that better gain in weight was seen than usual. There were no controls for this series. Schreiber ${ }^{8}$ reports a much better controlled series of cases. He treated eighty-five premature infants with ' unden' and compared the results with those of a previous series of premature infants of similar birth weight. There was no distinct difference in mortality and morbidity for the two groups but the weight curves showed a definite advantage for the 
treated cases. The infants receiving hormone gained $0 \cdot 4$ per cent. of their birth weight in the period of observation (eleven days on the average) while the untreated cases had lost $2 \cdot 4$ per cent. In ten pairs of twins there was an even more striking difference in favour of the treated infants. Schreiber employed the usual dosage of 100 M.U. per kgm. but he suggests that bigger doses might have yielded even better results. Brochier ${ }^{9}$ reports similar good results as regards gain in weight using four drops daily by the mouth of a solution of 'folliculin' containing 1000 international units (I.U.) per c.c. (The relation of M.U. to I.U. is discussed below.) This means approximately 250 I.U. daily. Brief reference to similar investigations with various ovarian hormones is also made by Devraigne and Sauphar ${ }^{10}$, Nobel ${ }^{11}$ and Bernheim-Karrer ${ }^{12}$. The lastnamed considers that on the whole the development of premature infants treated by ' unden' was no better than that of untreated babies.

Another method of using oestrin for premature babies has been to employ the blood or serum of pregnant women which is rich in ovarian hormone. Estimates of the dosage thus employed suggest that approximately 1 to 10 M.U. of oestrin was given daily either by injection or by the mouth. Beneficial results are claimed by v. Oettingen ${ }^{15}$, v. Raisz ${ }^{14}$, Schwartz $^{15}$ and Unbehaum ${ }^{16}$. Siegmund ${ }^{17}$ points out that the serum of pregnant women also contains prolan and he thinks it improbable that the good results obtained are due solely to the effects of known hormones.

Against these results, either with a preparation of oestrin or with the serum of pregnant women, Stork ${ }^{18}$ speaks strongly stating that he has seen no uniform good effects. With ' unden' in twelve premature babies (100 M.U. per kgm. daily for seven days) there were no beneficial results obtained. This author also experimented with 'prolan' but abandoned this because of disturbing symptoms. Edelstein ${ }^{19}$, who used injections of serum from pregnant women, also failed to find any beneficial effect.

The main impressions gained from the survey of the literature here summarized is that with certain exceptions the results reported are uncontrolled and too much emphasis is laid upon relatively slight evidence that treated infants made better progress than untreated babies. Few details are given as to other conditions, all of which are important for the premature baby, such as nursing, room temperature, and nourishment in particular.

\section{Present investigation.}

Any scientific attempt to assess the value of oestrin or any other form of treatment for premature babies must inevitably base its results upon mortality and morbidity rates and comparison of weight curves. The criteria for assessing the progress in premature infants have been set out elsewhere $^{20}$ and while the factors concerned are numerous and complex it is generally agreed that nursing care plays a dominant part. It follows, therefore, that any controlled investigation concerning premature 
infants must have constant conditions as regards nursing care and it is preferable that as far as possible the nurses concerned should be unaware which infants are receiving treatment and which are controls. This can best be achieved by the use of inert solutions for the control babies. This has, in fact, been carried out in the present investigation. Over a period of approximately two years, premature babies-that is to say babies weighing $5 \mathrm{lb}$. and under-born at Queen Charlotte's Hospital have received either treatment by oestrin or injection of the inert solvent solutions used for the oestrin. Alternate babies received either one or the other and in the case of twins of the requisite weight one received oestrin and one received the control solutions. The arrangements at the hospital are such that each of the three floors has a side room in which small and ill infants can be nursed apart from mothers and other infants. The arrangements as regards room temperature, the degree of humidity and methods of general hygiene and feeding are more or less constant throughout the hospital and all the babies have been supervised by the author. It will be seen that in this way valid contemporary controls have been obtained. In no other way can conditions be kept the same for a control series and it is useless, as some of the authors quoted above have done, to compare a treated series of babies with a previous group when there is no guarantee that all conditions will have been the same.

As will be seen below, when results are discussed, general mortality and morbidity rates give very little help in assessing the value of special forms of treatment since, where nursing skill is of a high standard, such rates are already remarkably low. Indeed, the experience gained during the past few years at Queen Charlotte's Hospital suggests that in expert hands the prognosis of the premature baby is remarkably good. If, however, it could be shown that any form of treatment improves the general condition of the premature baby, especially as regards promoting a steady gain in weight, it would be available for small babies in less favourable circumstances where it might turn the scale in their favour.

It is obvious that the gain in weight, which forms the basis of assessment in the results here reported, as well as in most of the previously published records, is dependent in main upon the fluid and food intake of the premature infant. This is governed by the skill of the attendant in inducing the infants to swallow and by the level of metabolism in the infant. In all the babies described in this series the methods of feeding were similar, the earliest 'feeds' offered being half-strength normal saline, followed by colostrum and dilute breast milk according to the stage and weight of the infant. In subsequent days undiluted breast milk and later a weak 'humanized' dried milk were used-the latter 
only when insufficient breast milk was available. The quantities offered were governed more or less by the amounts which the babies would take. These conditions of feeding were the same for all the babies, treated and untreated, so that it may fairly be assumed that the only variable factor was the condition of the infants in the general state and level of metabolism. If it could be shown that treated babies gained weight better than untreated babies this could be attributed to the stimulant effect of the treatment. On this basis comparison of weights of treated and untreated babies has been used as the main criterion for assessing the results. It would be ideal for babies under observation in this way to be weighed daily but such procedure necessitates in some cases more disturbance and exposure than it is wise to risk. Consequently, while in general babies were weighed daily, this procedure was omitted if the child's condition did not seem good. It has been possible from the general trend of the weight curves to calculate the weight on the seventh day of life in the few instances when this was not available.

Dosage.-The literature suggests that a standard dose among Continental workers was 100 ' mouse units' per kilogramme body weight. Schreiber $^{8}$, whose work is quoted above, in the most convincing of the published records, suggested that $\mathbf{b}$ gger doses might give more clear-cut results. It was consequently decided to begin with 100 M.U. per pound body weight, giving the total amount by one injection daily to the nearest half-pound. The first injection was given during the first twenty-four hours but not necessarily at the same time for each baby, so that the period elapsing between severing the cord and the injection of oestrin varied from a few to nearly twenty-four hours. The first group of babies actually received this dosage in the form of trihydroxyoestrin (' oestriol ') in olive oil in a strength of 1000 M.U. per c.c. The control infants received injections of olive oil. Ampoules containing the two solutions were labelled ' oestrin $A$ ', and ' oestrin $\mathbf{B}$ ' respectively so that the nursing staff were unaware of which received oestrin. Six premature infants received oestrin and there were seven control infants during the same period. The next group received ' menformon' in aqueous solution (supplied as already mentioned by the Organon Laboratories) which is ketohydroxyoestrin ('oestrone') in a dosage of 100 international units per pound body weight, the controls in this group being given injections of the aqueous solvent. Seven babies received this oestrin (' $C$ ') and there were six control babies over the same period ( ${ }^{\prime} D^{\prime}$ '). Examination of the results so far obtained indicated clearly that much larger numbers were necessary to determine the value of oestrin for premature infants. More ketohydroxyoestrin was supplied in olive oil (from British Drug Houses 
as already mentioned) and used in a dosage of 100 I.U. per pound of body weight (oestrin ' $\mathrm{K}$ ') whi'e control babies received injections of olive oil (oestrin ' $\mathbf{J}$ ') as before. In this group thirty-one babies received oestrin and there were twenty-three controls. (It is difficult to explain why there were fewer controls as alternate babies received either ' $\mathrm{K}$ ' or ' J.' The oestrin was supplied in ampoules containing 500 I.U. in 0.5 c.c. of olive oil and blank ampoules contained 0.5 c.c. of olive oil. Once an ampoule was opened its contents were either used at once or discarded. It might therefore happen that one ampoule supplied a daily dose for two babies or for one.)

It will be noted that apart from the six babies treated with ' oestrin A' (trihydroxyoestrin) the dosage was regulated in I.U. instead of M.U. as generally used in the literature summarized above. This change took place in conformity with the tendency among workers on other aspects of oestrin therapy and activity to discard the purely animal standards (rat and mouse units) in favour of the international unit. It would appear that one I.U. of ketohydroxyoestrin is about three to four times as active as one M.U. of trihydroxyoestrin, in so far as they are comparable. Thus the majority of the babies treated in this investigation received a very much higher dose of active oestrin than in any previously recorded study. To avoid confusion and to make the administration of the oestrin as easy as possible for the nursing staff no mention of the ' units' was made in this sense. Injections were made from insulin syringes in which 0.1 c.c. ws represented as a two units marked on the barrel. Thus 2 ' units' as marked on such a syringe was equivalent to 100 mouse or international units of oestrin.

\section{Results.}

Oestrin was injected as above described daily for the first seven days of life. This period was chosen partly as a result of what had been attempted elsewhere and partly because it was felt that any beneficial result would show itself during this period when the weight is tending to oscillate. The results given here are considered mainly under the headings of the weight on the seventh day and on the fourteenth day or earlier if the infant was discharged before this. There were so few deaths and so little general morbidity that no statistics are offered on these lines. Twins are considered separately and sex differences have been calculated for the third and largest group. During the period of two years that the investigation has been in progress there have been eighty babies under supervision whose records are analysed below. During the 
same period there have been fifty babies who came strictly within the definition of ' five pounds or under' who did not receive oestrin. There was no deliberate exc'usion of these babies but various circumstances combined to render them ineligible. Most of them were exactly or very nearly five pounds in weight, full-term infants who were nursed in the general wards, treated and behaving throughout like normal infants of full weight. In other cases the injections of oestrin were omitted on the first and second day and there seemed no point in complicating the clinical findings by including babies whose treatment was begun at varying periods. Babies dying on the first day of life did not receive oestrin. Two examples of gross abnormality were not treated (hydrocephalus and very large haemangioma). Four babies living for two days and one for four days were so ill from the start that oestrin was not given. Four infants receiving oestrin or control solutions died during treatment: one received one injection of oestrin $A$, and died on the second day of life, after repeated cyanotic attacks; one died on the thirteenth day, and is mentioned in Group I below; the other two were receiving control injections and died on the fourth and third day respectively (weights $1 \mathrm{lb} .8 \mathrm{oz}$. , and $3 \mathrm{lb} .14 \mathrm{oz}$. (one of triplets)). As far as possible the author saw every baby as often as was necessary (usually twice to three times weekly) and during holidays certain of the premature infants then born were also omitted from the investigation.

Group I. Oestrin 'A' and 'B.' Six babies received 100 M.U. of trihydroxyoestrin in olive oil per pound weight, by subcutaneous injection daily for seven days, and seven contemporary controls received olive oil only.

TABLE 1.

\begin{tabular}{|c|c|c|c|}
\hline$-\ldots$ & $\begin{array}{l}\text { Av. WT. } \\
\text { AT BIRTH. }\end{array}$ & $\begin{array}{c}\text { Av. WT. } \\
\text { SEVENTH DAY. }\end{array}$ & $\begin{array}{c}\text { Av. WT. } \\
\text { FOURTEENTH DAY. }\end{array}$ \\
\hline ' A' SERIES (TREATED) ... & 4lb. 2oz. (3lb. 14oz.) & 4lb. 5̃oz. (4lb.) .. & 4lb. 1oz. \\
\hline 'B' SERIES (UNTKEATED) & 4lb. 6oz. (4lb. 4oz.) & 4lb. 4oz. (4lb. 2oz.) & 4lb. $6 \mathrm{oz}$. \\
\hline
\end{tabular}

Figures in brackets show average for 4 babies in ' $A$ ' series and for $b$ babies in ' $B$ ' series who were weighed on fourteenth day.

Of babies receiving ' $A$ ' all did well except one who died on the thirteenth day of life with pneumonia. It appeared that his condition deteriorated after the oestrin was stopped on the seventh day. Four babies of this group were completely breast fed and two received mixed feeding (breast milk and modified cow's milk). The highest weight at 
birth was $4 \mathrm{lb}$. $13 \mathrm{oz}$, and the lowest $3 \mathrm{lb} .5 \mathrm{oz}$. Of babies used as controls all did well, six being completely breast fed and one receiving mixed feeding. The highest weight at birth was $4 \mathrm{lb} .14 \mathrm{oz}$., and the lowest $3 \mathrm{lb} .10 \mathrm{oz}$. There were no twins for comparison in this group. The results show a slightly better weight gain for the treated babies, but the numbers are small.

Group II. Oestrin 'C' and 'D.' Seven babies received 100 I.U. of ketohydroxyoestrin (menformon) in aqueous solution per pound of body weight, by subcutaneous injection daily for seven days. Six contemporary controls received the aqueous solvent only.

TABLE 2.

\begin{tabular}{|c|c|c|c|}
\hline & Av. WT. A'T BIETII. & $\begin{array}{c}\text { Av. WT. } \\
\text { SEVENTH DAY. }\end{array}$ & $\begin{array}{c}\text { Av. WT. } \\
\text { FOURTEENTH DAY. }\end{array}$ \\
\hline ' $\mathrm{C}$ ' SIRIES (TKEATED) ... & 4lb. 3oz. & 4lb. loz. & 一* \\
\hline ' I' SERIES (VNTREATED) & 3lb. $150 z$. & 3lb. 15oz. & 4lb. 5oz. \\
\hline
\end{tabular}

* All babies receiving ' $C$ ' except one were discharged before the fourteenth day.

Of babies receiving ' $\mathrm{C}$ ' all did well throughout except one weighing $3 \mathrm{lb}$, who developed fever on the fourth day, but quickly responded to extra fluid. All seven babies were breast fed. The highest weight at birth was $4 \mathrm{lb} .12 \mathrm{oz}$, and the lowest $3 \mathrm{lb}$. Of the babies used as controls, four did well throughout, one developed oedema and recovered, and one collapsed on the eighth day, but recovered. Four were breast fed and two received mixed feeding. The highest weight at birth was 4. lb. $12 \mathrm{oz}$., and the lowest $2 \mathrm{lb} .8 \mathrm{oz}$. One set of twins, both girls, responded as follows :-

Av. wt. at birth. Wt. seventh day. Av. fourteenth day.

$\begin{array}{llll}\text { Treated ' } \mathrm{C} \text { ' } \ldots & 4 \mathrm{lb} .3 \mathrm{oz} . & 4 \mathrm{lb} .7 \mathrm{oz} . & 5 \mathrm{lb} . \\ \text { Untreated }^{\prime} \mathrm{D}, & 3 \mathrm{lb} .14 \mathrm{oz} . & 4 \mathrm{lb} .1 \mathrm{oz} . & 4 \mathrm{lb} .6 \mathrm{oz} .\end{array}$

Both were breast fed and there is no appreciable difference between their progress. The results for the other babies did not show any material difference except that those in the control series did not lose so much weight.

Group III. Oestrin ' $\mathbf{K}$ ' and 'J.' Thirty-one babies received 100 I.U. of ketohydroxyoestrin in olive oil per pound body weight, by subcutaneous injection daily for seven days. Twenty-three contemporary controls received olive oil only. 
TABLE 3.

\begin{tabular}{|c|c|c|c|}
\hline & Av. WT. AT BIRTH. & $\begin{array}{c}\text { Av. WT. } \\
\text { SEVENTH DAY. }\end{array}$ & $\begin{array}{l}\text { Av. WT. } \\
\text { FOURTEENTH DAY. }\end{array}$ \\
\hline $\begin{array}{r}\text { ' } \mathrm{K} \text { ' SERIES (TREATED) } \\
\text { ALL BABIES }\end{array}$ & 3lb. $14 \mathrm{oz}$. & 3lb. 12oz. $(-3.2)$ & - \\
\hline $\begin{array}{l}\text { DitTo } 27 \text { BABIES REMAIN. } \\
\text { ING IN HOSPITAL UNTIL } \\
\text { FOURTENTH DAY }\end{array}$ & 3lb. $13 \mathrm{oz}$. & 3lb. 1loz. (-3.3) & 3lb. 15oz. $(+3.3)$ \\
\hline $\begin{array}{l}\text { 'J' SERIES (UNTREATED) } \\
\text { ALL BABIES }\end{array}$ & 4lb. $10 z$ & 3lb. 15oz. $(-3.1)$ & - \\
\hline $\begin{array}{l}\text { DITTO } 17 \text { BABIES REMAIN- } \\
\text { ING IN HOSPITAL UNTIL } \\
\text { FOURTEENTH DAY }\end{array}$ & $4 l b$. & 3lb. 13oz. $(-4.7)$ & 3lb. 14oz. $(-3.1)$ \\
\hline
\end{tabular}

Figures in brackets show percentage increase or decrease over birth weight.

Of babies receiving ' $K$ ' all did well throughout except one who became deeply jaundiced and recovered after two injections (10 c.c.) of maternal whole blood. One died at eight weeks old from gastroenterit.s. (It should be noted that no subsequent follow-up of babies has been attempted.) Twenty-one were breast fed and ten received mixed feeding. The highest weight at birth was $4 \mathrm{lb} .14 \mathrm{oz}$, , and the lowest $2 \mathrm{lb} .8 \mathrm{oz}$. Of the babies serving as controls all did well throughout except four : one was mildly jaundiced and lethargic, one developed oedema and recovered, one was very lethargic throughout and received thyroid extract as a stimulant after the fourteenth day, and one was very ill with cyanotic attacks and unexplained pyrexia, but recovered. Nineteen were breast fed and four received mixed feeding. The highest weight at birth was $4 \mathrm{lb} .12 \mathrm{oz}$, and the lowest $2 \mathrm{lb} .9 \mathrm{oz}$. It will be seen that by comparing the weights on the seventh day there is no material difference in the two groups, but by the fourteenth day the treated babies showed an average increase of 3.3 per cent. of their birth weight while the control babies were still 3.1 per cent. below birth weight. There is therefore a slight advantage in favour of the treated group. The two smallest babies in this group both did well, the details of their weights being as follows :-

Birth wt. Wt. seventh day. Wt. fourteenth day.

$\begin{array}{lllll}\text { Treated } & \ldots & 2 \mathrm{lb} .8 \mathrm{oz} . & 2 \mathrm{lb} .4 \mathrm{oz} . & 2 \mathrm{lb} .6 \mathrm{oz} . \\ \text { Untreated } & \ldots & 2 \mathrm{lb} .9 \mathrm{oz} . & 2 \mathrm{lb} .4 \mathrm{oz} . & 2 \mathrm{lb} .8 \mathrm{oz} .\end{array}$

Both received breast milk only. 
There were six sets of twins in this group and two surviving babies of one set of triplets. The average weights of these fourteen babies are as fol'ows, one of each set being treated :-

Birth wt. Wt. serenth day. Wt. fourteenth day.

$\begin{array}{lllll}\text { Treated } & \ldots & 3 \mathrm{lb} .15 \mathrm{oz} . & 3 \mathrm{lb} .13 \mathrm{oz} . & 4 \mathrm{lb} . \\ \text { Untreated } & \ldots & 3 \mathrm{lb} .15 \mathrm{oz} . & 3 \mathrm{lb} .14 \mathrm{oz} . & 4 \mathrm{lb} .1 \mathrm{oz} .\end{array}$

The untreated babies thus showed a slight advantage.

The results in this group have also been analysed for the two sexes. Very curiously thirty-three out of the fifty-four babies. were females, a marked sex preponderance.

TABLE 4.

\begin{tabular}{|c|c|c|c|c|c|c|}
\hline \multirow[b]{2}{*}{ Sex \& No. } & \multicolumn{2}{|c|}{ Av. WEIGHT AT BIRTH. } & \multicolumn{2}{|c|}{ Av. Weigiht SEVENTH DAY. } & \multicolumn{2}{|c|}{ Av. Weight Folktelenth DAY. } \\
\hline & $\mathrm{N}=11$ & $\mathrm{~F}=20$ & $\mathrm{M}=11$ & $\mathrm{~F}=20$ & & \\
\hline $\begin{array}{l}\text { 'K' SERIES } \\
\text { (TREATED) } \\
\text { ALL BABIES }\end{array}$ & 3lb. $15 \mathrm{oz}$. & 3lb. 13 oz. & 3lb. 12oz. $(-3.2)$ & 3lb. 12uz. $(-1 . b)$ & - & - \\
\hline SEx \& No. & $\mathrm{M}=9$ & $\mathrm{~F}=18$ & $\mathrm{M}=9$ & $\mathrm{~F}=18$ & $\mathrm{M}=9$ & $F=18$ \\
\hline $\begin{array}{l}\text { DITTO } 27 \text { BABILS } \\
\text { REMAINING IN } \\
\text { HOSPITAL UNTIL } \\
\text { FOURTEENTH DAY }\end{array}$ & 3lb. $13 \mathrm{oz}$. & $31 \mathrm{~b} .12 \mathrm{oz}$ & 3lb. 10oz. $(-4.9)$ & 3lb. 12oz. $\left(\begin{array}{ll}0\end{array}\right)$ & 316. 13oz. $(0)$ & 4lb. $(+6 \cdot 7)$ \\
\hline SEx \& No. & $M=10$ & $\mathrm{~F}=13$ & $M=10$ & $\mathrm{~F}=13$ & & \\
\hline $\begin{array}{l}\text { ' J' SERIES } \\
\text { (UNTREATFD) } \\
\text { AILL BARIES }\end{array}$ & 4lb. $20 z$ & 4lb. loz. & 31b. 15oz. $(-4.5)$ & 3lb. 15̄oz. $(-3.1)$ & - & - \\
\hline Sex \& No. & $M=8$ & $F=9$ & $M=8$ & $\mathrm{~F}=9$ & $M=8$ & $\mathbf{F}=\mathbf{9}$ \\
\hline $\begin{array}{l}\text { DITTO } 17 \text { BABIES } \\
\text { REMAINING IN } \\
\text { HOSPITAL UNTIL } \\
\text { FOIJRTEENTH DAY }\end{array}$ & 4lb. $10 z$ & 3lb. 14oz. & 31b. 12oz. $(-7.7)$ & 3lb. 13oz. $(-1.6)$ & 4lb. 1oz. $(0)$ & 3lb. 12oz. $-(3.2)$ \\
\hline
\end{tabular}

Figures in brackets show percentage increase or decrease over birth weight 
Analysed for differences in the two sexes the results show a more or less uniform advantage for the treated babies, i.e., less loss of weight, for the first seven days, in both sexes, the females losing slightly less than the males throughout. At the end of fourteen days the differences are more striking, the treated and untreated male babies being just back to birth weight while the females show a 6.7 per cent. increase for the treated series and a decrease of $\mathbf{3 . 2}$ per cent. for the untreated series. It would seem that the advantages shown for the two sexes together in table 3 must be mainly attributed to improvement effected in the female babies.

\section{Conclusions,}

A controlled series of investigations concerning in all eighty premature babies shows that subcutaneous injections of oestrin during the first seven days of life in doses of 100 M.U., trihydroxyoestrin (oestriol) 100 I.U., ketohydroxyoestrin (oestrone) per pound body weight have a slight stimulant effect as indicated by a better gain in weight than in babies not so treated. This improvement is more obvious in girl babies than in boy babies. The advantages produced by the oestrin injections do not appear definite enough to warrant the use of this substance as a routine measure for premature babies.

\section{Acknowledgments.}

The credit for the good results obtained with the large number of premature babies forming the object of this investigation must go to the Nursing Staff of Queen Charlotte's Hospital and especially to the ward sisters. Help has been obtained on various aspects of the problem from Dr. A. S. Parkes, Prof. E. C. Dodds, Dr. A. N. Macbeth (of Organon Laboratories), and Mr. E. R. C. Edyvean (of British Drug Houses, Ltd.), to whom the author tenders his thanks.

\section{REFERENGES.}

1. Aschheim, S., Arch. f. Gynäk., Berlin, 1927, CXXXII, 179.

2. Martin, E., Monatschr. f. Geburtsh. u. Gynäk., Berlin, 1929, LXXXII, 66.

3. Reiche, A., Ztschr. f. Kinderh., Berlin, 1930, XLIX,202.

4. Schiller, W., Arch. f. Gynäk., Berlin, 1931, CXLVII, 72.

5. Mügel, G., Monatschr. f. Geburtsh. u. Gynäk., Berlin, 1931, LXXXIX, 79.

6. Nölle, H., Zeitschr. f. Arztl. Fortbild., Jena, 1931, XXVIII, 112.

7. Kulka, E., Zentralbl. f. Gynäk., Leipzig, 1932, LVI, 2238.

8. Schreiber, F., ibid., 1933, LVII, 1318.

9. Brochier, A., Bull. Soc. d'obst. et de gynec., Paris, 1934, XXIII, 542. 
10. Devraigne, L., \& Sauphar, G., Rev. med. franc., Paris, 1932, XIII, 633.

11. Nobel, E., Wien. med. Wchnschr., Vienna, 1934, LXXXIV, 539.

12. Beinheim-Karrer, J., Schweiz. med. Wchnschr., Basle, 1934, LXIV, 8.

13. v. Oettingen, K., Zentralb. f. Gynäk., Leipzig, 1929, LIII, 2065.

14. v. Raisz, D., loc. cit., 2850.

15. Schwartz, E., Pediatra, Naples, 1932, XL, 1268.

16. Unbehaum, G., Zentralb. f. Gynäk., Leipzig, 1932, LVI, 2242.

17. Siegmund, H., ibid., 1933, LVII, 2000.

18. Stork, F., Arch. f. Kinderh., Berlin, 1933, XCIX, 109.

19. Edelstein, E., Zeitschr. f. Kinderh., Berlin, 1931, LI, 646.

20. Moncrieff, A., Lancet, Lond., 1935, i, 449. 